\title{
Sintesis Senyawa $N$-(2-Klorobenzoil)-N'-Fenilurea dan Uji Aktivitas Anti Kanker terhadap Sel HeLa
}

\section{(Synthesis and Anti cancer Activity Test against HeLa Cells from $N$-(2-Chlorobenzoyl)- $N$ '-Phenylurea)}

\author{
BAMBANG TRI PURWANTO* \\ Departemen Kimia Farmasi Fakultas Farmasi Universitas Airlangga \\ Kampus B Universitas Airlangga,Jl.Darmawangsa Dalam, Surabaya
}

Diterima 3 Agustus 2018, Disetujui 25 September 2018

\begin{abstract}
Abstrak: Beberapa senyawa turunan urea masih terus dikembangkan dalam upaya pencarian senyawa antikanker yang poten dengan efek samping minimal. Berkaitan dengan hal diatas ingin dikembangkan satu turunan urea yaitu senyawa N-(2-klorobenzoil)-yang merupakan turunan N'fenilurea. Metode sintesis adalah Schotten-Baumman yang telah di modifikasi, uji kemurnian dengan kromatografi lapis tipis menggunakan 3 macam pelarut eluasi yang berbeda. Karakterisasi struktur dengan menggunakan metode spektrofotometri UV dan IR, kemudian spektrometri ${ }^{1} \mathrm{H}-\mathrm{NMR}$ dan MS. Uji aktivitas antikanker terhadap sel Hella menggunakan metode MTT assay dan diperoleh nilai $\mathrm{IC}_{50^{\circ}}$. Rendemen senyawa $\mathrm{N}$-(2-klorobenzoil)-N'fenilurea sebesar 80,47 \% berupa kristal jarum berwarna putih. Uji kemurnian secara kromatografi lapis tipis dengan 3 pelarut eluasi berbeda (heksan:etil asetat:metanol $=2: 3: 1$; heksan:aseton $=4: 2$; heksan:etilasetat $=4: 2$ ) diperoleh satu noda tunggal yang berbeda harga $\mathrm{Rf}$ nya dibanding dengan senyawa asal $\mathrm{N}$-fenilurea. Titik Lebur senyawa adalah $149^{\circ} \mathrm{C}$ berbeda dengan senyawa asalnya $\mathrm{N}$-fenilurea. Uji aktivitas antikanker dengan metode MTT assay menggunakan sel Hella diperoleh hasil $\mathrm{IC}_{50} 2100 \mathrm{mg} / \mathrm{mL}$ atau $8,52 \mathrm{mM}$ sedang $\mathrm{IC}_{50}$ dari senyawa hidroksi urea sebagai pembanding $7537 \mathrm{mg} / \mathrm{mL}$ atau $99,10 \mathrm{mM}$. Senyawa N-(2-klorobenzoil)-N'fenilurea telah berhasil di sintesis dan dapat dikembangkan lebih lanjut sebagai senyawa anti kanker.
\end{abstract}

Kata kunci: Sintesis N-(2-klorobenzoil)-N'fenilurea, aktivitas anti kanker, sel HeLa.

\begin{abstract}
Several the urea derived compounds are still being developed in an effort to find the potent anti cancer compounds with the minimal side effects. In connection with the above matter, we want to develop an urea derivative, namely the compound is N- (2-chlorobenzoyl) -N'-phenylurea which is a derivative of the N-phenylurea. The synthesis method is the modified Schotten-Baumman, the purity test using thin layer chromatography using 3 different types of eluent solvents. Structure characterization using UV and IR spectrophotometry methods, then ${ }^{1} \mathrm{H}-\mathrm{NMR}$ spectrometry and MS. Anticancer activity test for the Hella cells using MTT assay method and obtained $\mathrm{IC}_{50}$ value. The yield of $\mathrm{N}$-(2-chlorobenzoyl) $-\mathrm{N}$ '-fenilurea compound is $80.47 \%$ on the form of white needle crystals. The purity test by thin layer chromatography with 3 different eluent solvents (hexan:ethyl acetate:methanol $=2: 3: 1$; hexan:acetone $=4: 2$; hexan:ethylacetate $=4: 2$ ) obtained a single stain which is different from the $\mathrm{Rf}$ value compared with the original $\mathrm{N}$-phenylurea compound. The melting point of the compound is $149^{\circ} \mathrm{C}$ which is different from the original compound $\mathrm{N}$-phenylurea. Anticancer activity test with MTT assay method using the Hella cells obtained $\mathrm{IC}_{50} 2100 \mathrm{mg} / \mathrm{mL}$ or $8.52 \mathrm{mM}$ and $\mathrm{IC}_{50}$ of hydroxy urea as the standard compound is $7537 \mathrm{mg} / \mathrm{mL}$ or $99.10 \mathrm{mM}$. N- (2-chlorobenzoyl) $-\mathrm{N}$ '-fenilurea compound has been successfully synthesized and can be further developed as an anticancer compound.
\end{abstract}

Keywords: Synthesis of N- (2-chlorobenzoyl) -N'-fenilurea; anticancer activity, HeLa cells.

\footnotetext{
* Penulis korespondensi, Hp. 08123536513

e-mail bambangsutony@gmail.com ; bambang-t-p@ff.unair.ac.id
} 


\section{PENDAHULUAN}

KANKER adalah salah satu penyakit penyebab utama kematian di negara berkembang dan juga di seluruh dunia. Dari 58 juta kematian di seluruh dunia dalam tahun 2005 , tercatat 7,6 juta $(13 \%)$ diantaranya disebabkan oleh kanker. Kematian yang disebabkan oleh penyakit kanker diperkirakan akan terus meningkat di tahun 2015 dan 11,4 juta orang di tahun 2030. Di Indonesia, kanker menjadi penyumbang kematian ketiga terbesar setelah penyakit jantung ${ }^{(1)}$. Hingga kini masih terus dilakukan usaha untuk menemukan obat antikanker baru karena obatobat yang sudah lama digunakan lambat laun menjadi kurang efektif dan ada kecenderungan resistensi ${ }^{(2)}$.

Obat anti kanker klasik yang digunakan dalam kemoterapi antara lain adalah golongan senyawa pengalkil, anti metabolit, antibiotika antrasiklin, alkaloida tanaman, inhibitor topoisomerase. Obatobat golongan tersebut menghambat pembelahan sel atau sintesis dan fungsi DNA dengan beberapa cara. Obat anti kanker baru tidak mempengaruhi DNA secara langsung, tetapi mempengaruhi molekul target spesifik yang diperlukan untuk karsinogenesis dan pertumbuhan sel kanker; dikenal dengan istilah molecularly targeted therapy ${ }^{(3)}$. Anti kanker yang termasuk golongan ini adalah inhibitor tirosin kinase (small molecule tyrosine kinase inhibitor) dan antibodi monoklonal. Tirosin kinase inhibitor yang telah menjadi obat antikanker antara lain: imatinib, gefitinib, dan erlotinib. Ahli onkologi meyakini bahwa terapi molekul target adalah kemoterapi masa depan ${ }^{(4)}$.

Pengembangan obat modern dilakukan melalui proses yang panjang serta memakan biaya yang tinggi, karena pada awalnya bersifat coba-coba (trial and error). Untuk meminimalkan sifat coba- coba, dilakukan rancangan obat (drug design), yaitu mengembangkan obat yang telah diketahui struktur molekul dan aktivitas biologisnya, atas dasar penalaran yang sistemik dan rasional ${ }^{(5)}$ dengan metode Hubungan Kuantitatif Struktur dan Aktivitas (HKSA). Dalam era komputer masa kini pendekatan hubungan struktur dan aktivitas dapat dilakukan secara lebih cepat dan terarah dengan "pemodelan molekul"

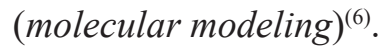

Langkah pertama dalam rancangan obat adalah menentukan senyawa penuntun (lead compound) yang akan di modifikasi strukturnya untuk memperoleh aktivitas yang dikehendaki, meningkatkan aktivitas atau selektivitasnya, atau menurunkan toksisitasnya ${ }^{(5)}$. Urea adalah salah satu dari lead compound yang menjadi induk dari sekian banyak turunan yang potensial sebagai anti kanker. Obat anti kanker turunan urea yang dikenal antara lain adalah karmustin atau BCNU (bis-chloroethylnitrosourea) dan ENU (N-etil$\mathrm{N}$-nitrosourea) yang termasuk senyawa pengalkil, serta hidroksiurea yang bekerja dengan menghambat enzim ribonukleotida reduktase (7). ENU dapat menginduksi mutasi dan juga toksik pada dosis tinggi. Struktur senyawa-senyawa tersebut ditampilkan pada Gambar 1.

Siswandono (1999) telah melakukan sintesis senyawa baru turunan benzoilurea yang mempunyai aktivitas pada sistem saraf pusat berupa gangguan gerak pada mencit ${ }^{(8)}$. Susilowati dan Diyah (2011) melaporkan bahwa $N$-benzoilurea, $N$-4-metoksibenzoilurea, dan 2-klorobenzoilurea menunjukkan efek sitotoksik berdasarkan BST (Brine Shrimp Letality Test), sehingga berpotensi sebagai antikanker ${ }^{(9)}$. Aktivitas sitotoksik senyawa tersebut lebih tinggi daripada hidroksiurea yang telah dikenal sebagai obat antikanker.

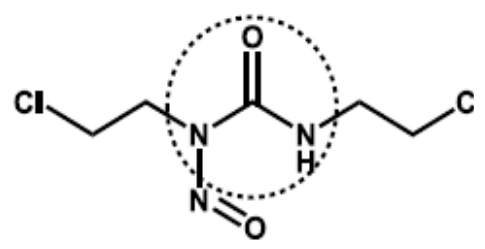

(a)

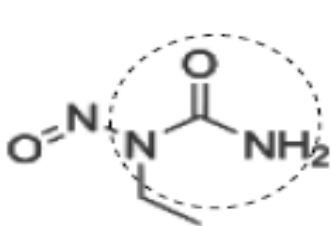

(b)

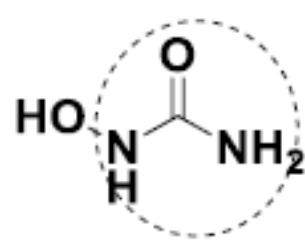

(c)

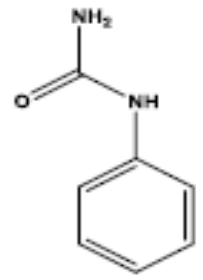

(d)

Gambar 1. Struktur Karmustin (a), ENU (b), hidroksiurea (c), dan N-fenilurea (d).

Hidroksiurea dan turunan asam hidroksamatnya dilaporkan bekerja dengan mempengaruhi target enzim spesifik yang terlibat dalam perkembangan kanker seperti histon deasetilase, matriks metaloproteinase
(MMP), dan RNR ${ }^{(10)}$. Hardjono (2011) telah melakukan modifikasi struktur urea dengan mensintesis 9 turunan 1-(benzoiloksi)urea dan menyimpulkan bahwa ada hubungan linear antara aktivitas sitotoksik in-vitro 


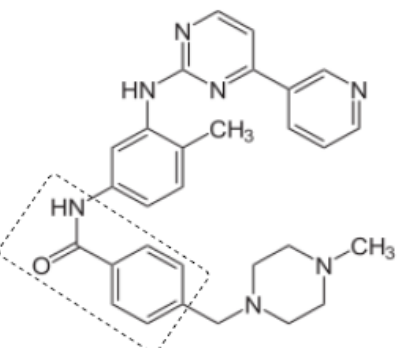

(a)

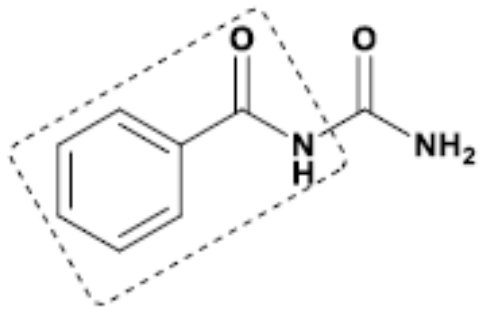

(b)

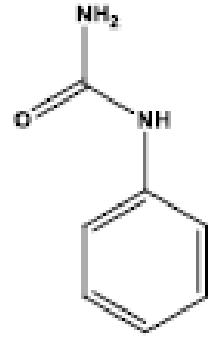

(d)

Gambar 2. Struktur Imatinib (a), N-benzoilurea (b), dan N-fenilurea (d)

terhadap se HeLa dengan prediksi aktivitas secara in silico melalui pemodelan molekul. Aktivitas sitotoksik turunan 1-(benzoiloksi)urea lebih tinggi dibanding hidroksiurea $^{(11)}$.

Dalam usaha mendapatkan senyawa antikanker baru dilakukan dilakukan modifikasi struktur urea. Struktur senyawa anti kanker mengandung gugus $\mathrm{NH}-\mathrm{CO}-\mathrm{NH}$ yang merupakan gugus farmakoforik. Pada beberapa senyawa, farmakofor tersebut berada dalam cincin heterosiklik aromatik atau dalam heterosiklik nonaromatik, sebagai $-\mathrm{NH}$ atau $-\mathrm{N}-{ }^{(12)}$. Dengan mempertahankan farmakofor - NH-CO-NHserta menambahkan gugus halogen berupa klorida dan gugus aromatik, akan dibuat senyawa turunan fenilurea (Gambar 2).

Untuk optimasi aktivitas anti kanker, dilakukan modifikasi struktur senyawa fenilurea berdasarkan perubahan sifat lipofilik, sterik, dan elektronik senyawa. Modifikasi sifat lipofilik dan elektronik dilakukan menurut model Topliss ${ }^{(13)}$, yaitu memasukkan substituen pada cincin benzena yang diprediksi akan menghasilkan senyawa dengan aktivitas lebih tinggi daripada senyawa induk. Substituen metil (-CH3) yang non polar akan meningkatkan sifat lipofilik, sedangkan substituen yang elektronegatif seperti metoksi, kloro, dan trifluorometil akan mengubah sifat elektronik senyawa. Modifikasi sifat sterik dihasilkan dari perubahan ukuran gugus benzoil yang telah disubstitusi ${ }^{(14)}$. Senyawa, turunan fenilurea dapat disintesis melalui reaksi antara senyawa fenilurea dengan turunan benzoil klorida berdasarkan metode Schotten-Baumann ${ }^{(15)}$.

Untuk menguji aktivitas antikanker dilakukan penentuan aktivitas hambatan pertumbuhan sel secara in vitro ${ }^{(16)}$. Kultur sel tumor yang digunakan adalah sel karsinoma serviks (Sel HeLa). Aktivitas hambatan pertumbuhan sel dinyatakan dalam $\mathrm{IC}_{50}$, yaitu kadar obat yang dapat mengakibatkan kematian $50 \%$ sel tumor ${ }^{(17)}$.

Dari penelitian ini akan diperoleh senyawa baru turunan $\mathrm{N}$-fenilurea yang dapat dimanfaatkan sebagai obat anti kanker.

\section{BAHAN DAN METODE}

BAHAN. Fenilurea, 2-klorobenzoil klorida, piridin, berbagai pelarut organik (aseton, etil asetat, n-heksana, kloroform, etanol, dan metanol dengan kualitas pro analisa), Kieselgel 60 F254, DMSO-d6. Bahan untuk uji aktivitas : Senyawa hasil sintesis, kultur sel HeLa, Media Kultur DMEM, DMSO, dapar fosfat salin (PBS), MTT (3-(4,5-dimetiltiazol-2-il)-2,5difeniltetrazolium bromida), SDS $10 \%$ dalam $0,1 \mathrm{~N}$ $\mathrm{HCl}$.

Alat. Alat gelas di laboratorium, Spektrofotometer UV-vis Shimadzu HP, 8452 A, Spektrofotometer Jasco FT-IR 5300, Spektrometer, NMR Hitachi R-1900, Electrothermal Mel-Temp, Corning Hot Plate P 351, Neraca analitik Shimadzu LM-20. Alat untuk uji sitotoksik : Mikropipet 200, $1000 \mu \mathrm{L}$ dan tip, tabung reaksi, microplate, Conical tube, ELISA-Reader.

METODE. Prosedur Sintesis Senyawa $\mathrm{N}-(2-$ klorobenzoil)-N'fenilurea. Pada labu alas bulat 200 $\mathrm{mL}$; 0,03 mol fenilurea dicampur dengan $40 \mathrm{~mL}$ tetrahidrofuran dan $4 \mathrm{~mL}$ piridin. Pada suhu $5{ }^{\circ} \mathrm{C}$ ditambahkan larutan 2-klorobenzoil klorida $0,01 \mathrm{~mol}$ dalam $20 \mathrm{~mL}$ tetrahidrofuran, sedikit-sedikit sambil diaduk dengan pengaduk magnetik. Setelah larutan 2-klorobenzoil klorida habis, campuran direfluks dan diaduk selama 3 jam.

Setelah reaksi dihentikan, tetrahidrofuran diuapkan pada rotavapor. Pada hasil reaksi ditambahkan larutan natrium bikarbonat jenuh sambil diaduk sampai tidak terjadi gelembung udara (buih). Hasil disaring dengan corong Buchner, zat padat dicuci dengan $50 \mathrm{~mL}$ air 2 kali, kemudian dicuci dengan $10 \mathrm{~mL}$ etanol 2 kali. Dilakukan rekristalisasi dengan cara melarutkan zat padat dengan etanol secukupnya sambil diaduk di atas pemanas (hot plate). Larutan disaring dalam keadaan panas, filtrat dibiarkan dalam suhu kamar sampai dingin dan dibiarkan semalam. Kristal yang terbentuk disaring dengan corong Buchner, dicuci dengan 10 $\mathrm{mL}$ etanol 2 kali. Tergantung senyawa hasil sintesis yang diperoleh, rekristalisasi dapat dilakukan dengan pelarut lain yang sesuai, seperti aseton-air. Kristal 
yang terbentuk dipidahkan ke cawan petri, kemudian dikeringkan dalam oven pada suhu $50^{\circ} \mathrm{C}$ sampai berat konstan $^{(18)}$.

Uji Kemurnian dan Identifikasi Struktur Senyawa. Uji kemurnian senyawa-senyawa hasil sintesis dilakukan dengan kromatografi lapisan tipis, dengan fase diam lempeng aluminium Silika gel $\mathrm{GF}_{254}$ E. Merck dan penampak noda lampu UV. Penentuan titik lebur dilakukan dengan Electrothermal melting point apparatus. Identifikasi struktur senyawa hasil sintesis dilakukan dengan spektrofotometer ultraviolet (UV) dan infra merah (IR), spektrometer resonansi magnet inti $\left({ }^{1} \mathrm{H}-\mathrm{NMR}\right)$ dan spektrometer massa (MS) $)^{(19)}$.

Uji Aktivitas Anti kanker. Aktivitas anti kanker atau uji sitotoksik secara in vitro dengan sel kanker menggunakan metode MTT. Disiapkan larutan induk dari 10 senyawa uji dengan kadar $5000 \mu \mathrm{g} / \mathrm{mL}$ dalam pelarut DMSO. Dari masing-masing larutan induk dibuat satu seri larutan baku kerja konsentrasi 250, $500,750,1000,1500,2000 \mu \mathrm{g} / \mathrm{mL}$; dengan cara pengenceran. Juga dibuat larutan obat antikanker standar (hidroksiurea) sebagai kontrol positif dan blanko pelarut sebagai kontrol negatif.

Disiapkan kultur sel kanker (sel HeLa) dan sel normal berupa suspensi sel dengan kepadatan $10^{5}-2 \times 10^{6}$. Kemudian sel dimasukkan ke dalam sumuran Microplate, masing-masing $100 \mu \mathrm{L}$, kecuali sumuran yang digunakan sebagai kontrol media. Sebanyak 0,2 $\mathrm{mL}$ dari masing-masing baku kerja, kontrol positif dan kontrol negatif dimasukkan dalam sumuran microplate. Untuk tiap konsentrasi larutan baku kerja dibuat replikasi 3. Microplate diinkubasi dalam inkubator $5 \% \mathrm{CO}_{2}$ selama 24 jam pada suhu $37{ }^{\circ} \mathrm{C}$ dan $\mathrm{pH}$ 7,4-7,7. Disiapkan reagen MTT untuk perlakuan $(0,5 \mathrm{mg} / \mathrm{mL})$ dengan mengencerkan $1 \mathrm{~mL}$ stok MTT (50 mg MTT dalam $10 \mathrm{~mL}$ PBS) dengan

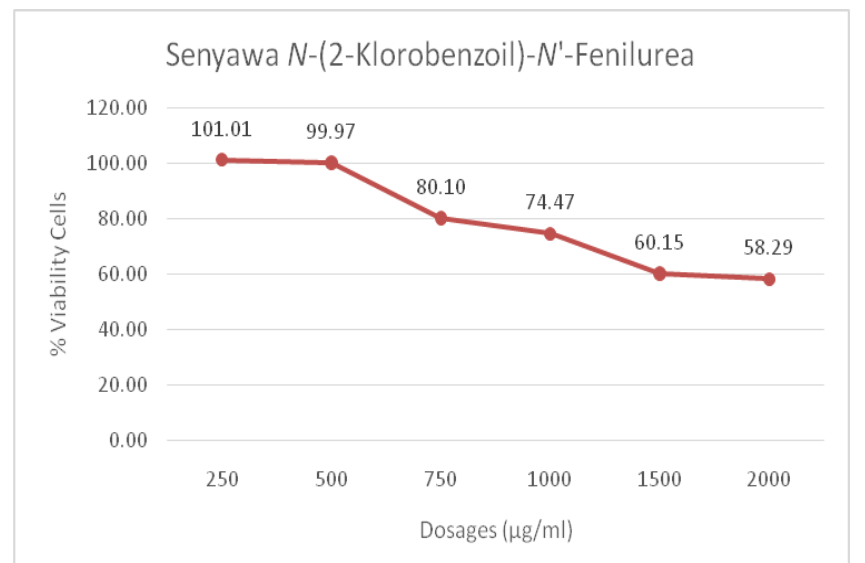

Gambar 3. Kurva aktivitas anti kanker senyawa N-(2klorobenzoil)-N'fenilurea terhadap sel HeLa. media secukupnya.

Setelah inkubasi, media sel dibuang dan sel dicuci PBS kemudian ditambahkan reagen MTT $100 \mu \mathrm{L}$ ke setiap sumuran, termasuk kontrol media (tanpa sel). Plate diinkubasi $2-4$ jam dalam inkubator $\mathrm{CO}_{2}$. Setelah terbentuk formazan ditambahkan $100 \mu \mathrm{L}$ SDS $10 \%$ dalam $0,1 \mathrm{~N} \mathrm{HCl}$. Plate dibungkus dengan kertas alumunium dan inkubasikan di tempat gelap pada temperatur kamar selama semalam. Selanjutnya absorbansi masing-masing sumuran diamati dengan ELISA reader pada $595 \mathrm{~nm}$. Makin banyak sel yang hidup, absorbansi makin besar. $\mathrm{IC}_{50}$ dari senyawa uji ditentukan dengan analisis regresi probit. Prosedur yang sama dilakukan pula untuk sel normal ${ }^{(20,21)}$.

\section{HASIL DAN PEMBAHASAN}

Sintesis N-(2-klorobenzoil)-N'fenilurea. Hasil sintesis senyawa N-(2-klorobenzoil)-N'fenilurea berupa kristal berwarna putih bentuk seperti jarum dengan rendemen sebesar 80,47\%.

Struktur Karakterisasi Senyawa N-(2klorobenzoil)-N'fenilurea. N-(2-klorobenzoil)N'fenilurea , $\lambda \max (\mathrm{nm})=262,300,304$; IR, 3444 cm-1 (NH sekunder), $1787 \mathrm{~cm}-1$ (-CO karbonil), $1592 \mathrm{~cm}-1(\mathrm{C}=\mathrm{C}$ arom); 1-HNMR (DMSO-d6), 7,00 - 8,40 ,m, (C6H5); 10,80, s, (NH); 10,97,s, (NH); $\operatorname{MS}(\mathrm{EI})(\mathrm{m} / \mathrm{e}), 274(\mathrm{M})+, 112(\mathrm{ClC} 6 \mathrm{H} 5)+, 120$ $(\mathrm{C} 6 \mathrm{H} 5 \mathrm{CONH})+, 139(\mathrm{ClC} 6 \mathrm{H} 5 \mathrm{COH})+$.

Uji Aktivitas Anti Kanker Senyawa N-(2klorobenzoil)-N'fenilurea. Setelah dilakukan uji antikanker terhadapa sel HeLa dari senyawa N-(2klorobenzoil)-N'fenilurea dengan menggunakan metode MTT assay dan hasilnya dapat dilihat pada Gambar 3 dan 4.

Untuk melakukan sintesis senyawa N-(2klorobenzoil)-N'fenilurea dilakukan dengan cara

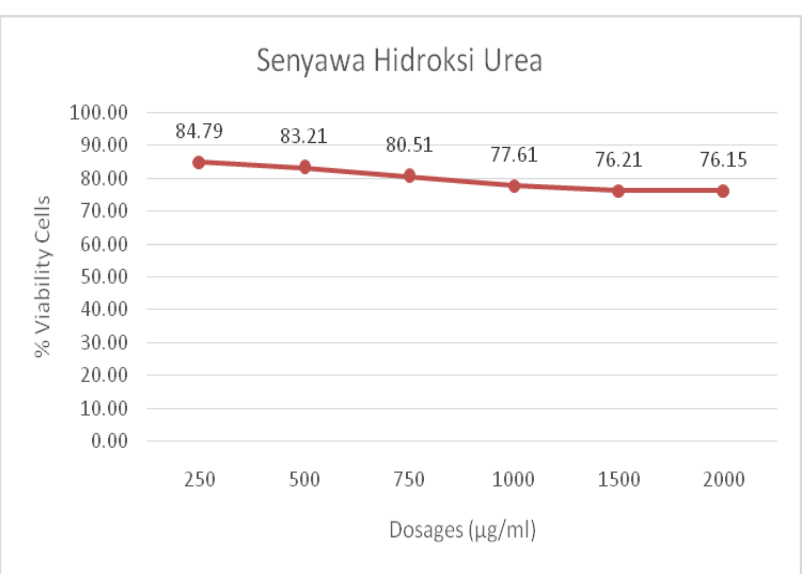

Gambar 4 : Kurva aktivitas anti kanker senyawa pembanding hidroksi urea terhadap sel HeLa. 
mereaksikan antara gugus amina primer dari $\mathrm{N}$-fenilurea dengan gugus benzoil dari senyawa 2-klorobenzoil klorida. Beberapa peneliti telah melakukan beberapa metode reaksi antara gugus amina primer dengan turunan benzoil klorida, Reksohadiprodjo (1981) dan Tjiptasurasa (1991) telah melakukan reaksi asilasi antara turunan urea dengan asil klorida, metode yang digunakan adalah dengan melakukan pencampuran dan pemanasan pada suhu $60-80{ }^{\circ} \mathrm{C}$. Ternyata hasil yang diperoleh memiliki rendemen yang relatif kecil (9-31\%), hal ini dapat disebabkan kurangnya kontak antar senyawa karena tidak adanya media pelarut yang digunakan.

Metode diatas digunakan oleh peneliti karena turunan urea memiliki sifat kelarutan yang berbeda dengan turunan asil klorida, turunan urea merupakan senyawa yang mudah larut air sedangkan turunan asil klorida sebaliknya. Pada pelaksanaan reaksi asilasi ini dihindari adanya air karena dapat bereaksi dengan turunan benzoil klorida dan akan membentuk asam benzoat begitu pula pelarut alkohol sebaiknya tidak digunakan karena akan membentuk senyawa ester bila bereaksi dengan turunan benzoil klorida. Pada reaksi asilasi, turunan benzoil klorida dapat bereaksi dengan cepat dan sempurna dengan senyawa amina primer, sekunder ataupun tersier pada penggunaan pelarut piridin dan memberikan prosentase hasil yang relatif cukup baik ${ }^{(22,23)}$

Pada reaksi asilasi antara senyawa urea dengan turunan asil klorida, secara teoritis kedua gugus amina primer dapat bereaksi dengan turunan asil klorida, tetapi dari hasil penelitian yang telah dilakukan oleh Reksohadiprodjo (1987) dan Tjiptasurasa (1991) menunjukkan bahwa hanya satu gugus amina primer dari senyawa urea yang bereaksi dengan turunan asil klorida.

Hal tersebut disebabkan adanya pengaruh halangan ruang dari inti aromatis sehingga akan mengganggu reaksi selanjutnya. Pada reaksi asilasi tersebut akan dilepaskan $\mathrm{HCl}$ yang dapat mengganggu jalan nya reaksi, karena gugus amida yang terbentuk akan dapat dipecah kembali, oleh karena itu dapat diatasi dengan penambahan 2 ekivalen senyawa amina. Cara lain untuk mengatasi masalah diatas adalah dengan menetralisir $\mathrm{HCl}$ yang terbentuk dengan penambahan basa kuat seperti larutan natrium hidroksida atau kalium hidroksida. Reaksi antara senyawa amin dengan asil klorida yang menggunakan pelarut organik dikenal dengan reaksi Schotten-Baumann ${ }^{22,23)}$.

Siswandono (1999), telah melakukan reaksi asilasi antara senyawa urea dengan turunan benzoil klorida, ternyata reaksi ini mengalami kesukaran disebabkan senyawa urea larut dalam pelarut polar sedang turunan benzoil klorida larut dalam pelarut non polar, oleh karena itu digunakan pelarut tetrahidrofuran yang akan membentuk suspensi dengan senyawa urea kemudian direaksikan dengan turunan benzoil klorida yang dilarutkan dalam tetrahidrofuran pula( ${ }^{(8)}$.

Pada pembentukan senyawa N-(2-klorobenzoil)$\mathrm{N}$ 'fenilurea, reaksi juga dilakukan dengan cara mereaksikan antara senyawa $\mathrm{N}$-fenilurea dengan turunan 2-klorobenzoil klorida menggunakan pelarut reaksi tetrahidrofuran, dan direfluks selama 8 jam. Setelah reaksi selesai kemudian ditambahkan larutan natrium karbonat jenuh untuk menetralisir $\mathrm{HCl}$ dan turunan asam benzoat yang terbentuk. Langkah selanjutnya adalah melakukan pencucian dengan air untuk menghilangkan sisa-sisa garam $\mathrm{HCl}$ yang ada, kemudian dilakukan pencucian dengan metanol untuk menghilangkan sisa senyawa 2-klorobenzoil klorida atau hasil hidrolisa nya yaitu turunan asam benzoat. Tahap berikutnya adalah melakukan rekristalisasi dengan metanol panas, karena senyawa N-(2klorobenzoil)-N'fenilurea larut dalam metanol panas tapi tidak larut dalam kondisi dingin. Pada umumnya hasil rekristalisasi dari senyawa N-(2-klorobenzoil)$\mathrm{N}$ 'fenilurea berupa kristal jarum kecil mengkilat atau keping mengkilat.

Senyawa-senyawa hasil sintesis yang sudah terbentuk kemudian diuji kemurniannya dengan kromatografi lapis tipis (KLT) menggunakan tiga fasa gerak yaitu campuran heksan:etil asetat: metanol (2:3:1), campuran heksan:aseton (4:2) dan heksan :etil asetat (4:2). Hasil KLT menunjukkan bahwa pada berbagai fasa gerak yang dipergunakan diatas noda yang ada hanya satu, hal ini berarti bahwa kemungkinan senyawa hasil sintesis merupakan senyawa tunggal.

Tahap selanjutnya adalah melakukan uji kemurnian dengan penentuan jarak lebur dari senyawa-senyawa hasil sintesis. Hasil penentuan jarak lebur senyawa hasil sintesis menunjukkan bahwa jarak lebur nya relatif kecil yaitu berkisar dua derajat celcius, hal ini berarti senyawa-senyawa hasil sintesis murni.

Identifikasi Struktur Senyawa N-(2klorobenzoil)-N'fenilurea. Pada penentuan panjang gelombang senyawa $\mathrm{N}$-(2-klorobenzoil)-N'fenilurea dengan menggunakan spektrofotometer UV dapat terlihat bahwa senyawa hasil sintesis menunjukkan 2 panjang gelombang maksimum yaitu $204 \mathrm{~nm}$ dan $232 \mathrm{~nm}$, diduga senyawa hasil sintesis memiliki gugus kromofor ikatan rangkap terkonyugasi atau sistem aromatik dan gugus auksokrom. Dari spektra UV juga terlihat adanya pergeseran panjang gelombang maksimum.

Pada bahan reaksi $\mathrm{N}$-fenilurea menunjukkan 2 panjang gelombang yaitu $204 \mathrm{~nm}$ dan $238 \mathrm{~nm}$, sedang senyawa hasil sintesis juga menunjukkan 3 panjang 
gelombang maksimum yaitu $262 \mathrm{~nm}, 300 \mathrm{~nm}$ dan 304 $\mathrm{nm}$, hal ini menunjukkan bahwa terjadi penambahan gugus kromofor pada struktur benzoil sehingga bisa dikatakan bahwa reaksi asilasi antara senyawa $\mathrm{N}$-fenilurea dan senyawa 2-klorobenzoil klorida telah berlangsung seperti yang diharapkan.

Pada spektrum IR senyawa N-(2-klorobenzoil)N'fenilurea terlihat adanya pita didaerah $3444 \mathrm{~cm}^{-1}$ yang menunjukkan gugus amina sekunder dari senyawa amin aromatis, hal ini didukung pula oleh spectra $1 \mathrm{H}-\mathrm{NMR}$ dengan adanya dua pita tajam didaerah 10,80 dan 10,97 ppm yang menunjukkan adanya masing-masing 1 atom $\mathrm{H}$ singlet dari gugus amina sekunder (gugus $\mathrm{CONH}$ ). Adanya dua gugus karbonil terlihat pada spektrum IR pada bilangan gelombang 1787 dan $1676 \mathrm{~cm}^{-1}$, sedang untuk gugus $-\mathrm{C}=\mathrm{C}$ - terlihat pada bilangan gelombang 1592 . Hal ini diperkuat spektrum ${ }^{1} \mathrm{H}-\mathrm{NMR}$ yang menunjukkan multiplisitas yang multiplet dengan 10 atom $\mathrm{H}$ dari dua inti aromatis pada pergeseran kimia 7,00-8,40 ppm.

Dari analisis spektrum-spektrum di atas dapat disimpulkan bahwa senyawa adalah N-(2klorobenzoil)-N'fenilurea dengan rumus struktur kimia sebagai berikut:

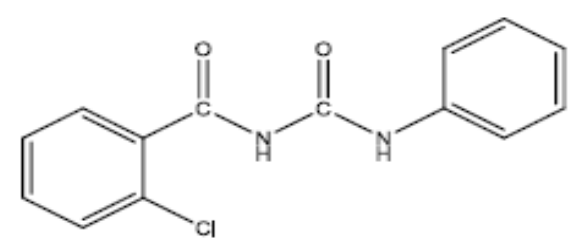

N-2-klorobenzoil-N'fenilurea.

Dari data aktivitas anti kanker terhadap sel HeLa, senyawa N-(2-klorobenzoil)-N'fenilurea memiliki aktivitas anti kanker yang lebih tinggi dibandingkan dengan senyawa hidroksi urea yang dapat dilihat dari $\mathrm{IC}_{50}$ nya, $\mathrm{IC}_{50}$ senyawa $\mathrm{N}$-(2-klorobenzoil)N'fenilurea: $2100 \mathrm{mg} / \mathrm{mL}$ atau $8,52 \mathrm{mM}$, sedangkan senyawa hidroksi urea sebagai senyawa pembanding: $7557 \mathrm{mg} / \mathrm{mL}$ atau 99,10 mM. Aktivitas yang lebih tinggi karena adanya gugus fenil pada senyawa fenilurea yang akan meningkatkan nilai parameter lipofiliknya ( $\log$ P: 3,02$)$ sehingga akan meningkatkan kemampuan senyawa N-(2-klorobenzoil)-N'fenilurea dalam penembusan ke dalam membran biologis sel HeLa, selain itu adanya penambahan gugus benzoil pada senyawa N-(2-klorobenzoil)-N'fenilurea diperkirakan akan meningkatkan interaksi senyawa $\mathrm{N}$-(2-klorobenzoil)-N'fenilurea dengan reseptornya sehingga aktivitas anti kanker terhadap sel HeLa semakin tinggi. Adanya gugus klorida pada posisi orto yang terikat langsung dengan inti benzen juga akan meningkatkan sifat lipofilik dari senyawa N-(2klorobenzoil)-N'fenilurea sehingga akan memperkuat penembusan kedalam membran biologis juga, yang akan berakibat terjadinya peningkatan aktivitas anti kankernya.

\section{SIMPULAN}

Senyawa N-(2-klorobenzoil)-N'fenilurea telah berhasil di sintesis dan memiliki aktivitas anti kanker terhadap sel HeLa yang lebih tinggi dibanding senyawa hidroksi urea, sehingga dapat dikembangkan sebagai senyawa baru dengan aktivitas anti kanker.

\section{DAFTAR PUSTAKA}

1. DepKes RI. Departemen Kesehatan Bentuk Subdirektorat Kanker. TEMPO Interaktif. 2006: diakses pada 14 Maret 2010.

2. Kar A. Medicinal chemistry. $4^{\text {th }}$ ed. New Delhi: New Age International Ltd Publishers; 2007. pp. 794 - 810

3. Zhukov NV, Tjulandin SA. Targeted therapy in the treatment of solid tumors: practice contradicts theory. Biochemistry Mosc. 2008.73(5): 605-18.

4. Avendano $\mathrm{C}$ and Menendes JC. Amsterdam: Medicinal chemistry of anticancer drugs, Elsevier; 2008. 13-18.

5. Siswandono dan Soekardjo,B. Kimia Medisinal I \& II, Surabaya: Airlangga University Press; 2000.

6. Abraham, DJ. Burger's medicinal chemistry and drug discovery. Sixth Edition, Volume 1. New York: Drug Discovery, John Wiley and Sons; 2003.

7. Platt OS. Hydroxyurea for the treatment of sickle cell anemia. N. Engl. J. Med. 2008. 358(13):1362-9.

8. Siswandono. Sintesis senyawa baru turunan asil dan Benzoil-N-Urea untuk optimasi aktivitas penekan sistem saraf pusat. Jakarta: Laporan Penelitian Riset Unggulan Terpadu VI, Kementerian Ristek RI, LIPI; 1999.

9. Susilowati R, Diyah NW, Sulistiawan A, Lestari YM. Aktivitas sitotoksik turunan N-Benzoilurea. Surabaya: Laporan Penelitian Fakultas Farmasi Unair; 2011.

10. Saban N, Bujak M. Hydroxyurea and hydroxamic acid derivatives as antitumor drugs. Cancer Chemother Pharmacol. 2009.64:213 - 21.

11. Hardjono. Modifikasi struktur 1-(Benzoiloksi)urea dan hubungan kuantitatif struktur aktivitas sitotoksiknya [disertasi]. Surabay: Fakultas Sains dan Teknologi Universitas Airlangga; 2011.

12. Moreau E, Fortin S, Lacroix J, Patenaude A. N-PhenylN0-(2-chloroethyl)ureas (CEUs) as potential antineoplastic agents. Part 3: Role of carbonyl groups in the covalent binding to the colchicine-binding site. Bioorganic \& Medicinal Chemistry. 2008.16:1206-17.

13. Taylor JB, Kennewell PD. Modern medicinal Chemistry. Chichester: Ellis Horwood Limited; 1993. pp 272-5.

14. Diyah NW, Purwanto, Siswandono, Hardjono, S, 
Purwanto BT, Susilowati R. The structure modification and analgesic activities of o-benzoylsalicylic acid derivatives. Penang: USM-UNAIR First Collaborative Conference; 2007.

15. Clayden G, Warren, Wothers. Organic chemistry. New York: Oxford University Press; 2001. 279-303.

16. Fortin S, Moreau E, Patenaude A, Desjardins M, Lacroix J, Rousseau JLC, and Rene' C-Gaudreaulta R. Optimized N-phenyl-N0-(2-chloroethyl)ureas as potential antineoplastic agents: Synthesis and growth inhibition activity. Bioorganic \& Medicinal Chemistry. 2005.13:6703-12.

17. Lie JN, Song D, Lin YH, Hu QY, Yin L, Bekesi, $\mathrm{G}$, et al. Inhibition of microtubule polymerization by 3-Bromopropionylaminobenzoylurea (JIMB01), a new cancericidal tubulin ligand. Biochemical Pharmacology. 2003.65:1691-99.

18. Mc Murry JM. Organic chemistry. Belmont: Broke/ Cole; 2008. pp 263-89; 779-851.

19. Silverstein RM, Webster FX, and Kiemle DJ. Spectrofotometric identification of organic compound. $7^{\text {th }}$ ed. New York: John Wiley and Sons; 2005.
20. Al-Amin M \& Rabiul IM. Cytotoxicity study of some ketone schiff bases and heterocyclic compounds. Dhaka University Journal of Pharmaceutical Sciences. 2005.4(1).

21. McLaughlin JL. Crown gall tumour on potato discs and brine shrimp lethality: Two simple bioassays for higher plant screening and fractionation. London: Academic Press Limited; 1991.

22. Reksohadiprodjo MS. Transformation of fusel oil from Indonesian alcohol factories into products of higher value [unpublished dissertation]. Yogyakarta: Gadjah Mada University; 1981. pp. 134, 145-152.

23. Tjiptasurasa. Komponen minyak fusel Indonesia, isolasi dan oksidasinya, sintesis dan evaluasi farmakokimia beberapa senyawa turunannya [unpublished Dissertation]. Yogyakarta: Universitas Gadjah Mada; 1991. 